\title{
THE CONCEPT OF INNOVATION IN THE APPROACH TO NOVELTY, VALUE CREATING, INTERACTION PROCESSESAND SOCIAL PROGRESS
}

\author{
Edita Baranskaité丶 ${ }^{1}$, Daiva Labanauskaité丶 ${ }^{2}$ \\ Klaipèda University (Lithuania)
}

\begin{abstract}
Countries and businesses focus on processes optimization aiming to cut cost and increase profit. The main keyword for achieving it is usually "innovations". Innovations is one of the most popular trends in most economies and businesses. The paradox is that there is the lack of understanding the concept both in business and science. The term of innovations is not a new topic in the research literature. However, the problem is that the definition of the concept of innovations is constantly evolving and there is no clear definition. The paper aims to define the concept of innovations and identify the changes in the concept by reviewing the scientific literature. Literature analysis revealed that the development of innovations concept started in 1934, approaching the concept from the novelty perspective. Later new perspectives were introduced such as interaction processes, value creation and social progress. Today the concept can be defined as following: innovation is a company or consumer-initiated economic, managerial, psychological or technological process of renewal within a company, which results in greater added value and a competitive advantage.

KEYWORDS: innovations concept, innovations in economics.
\end{abstract}

JEL CODES: O31, O39

DOI:

\section{Introduction}

Nowadays innovation is a very popular and widely used term/concept, seen as the source of businesses or countries wealth. Many companies and countries sets the goal for themselves to innovate, invest huge funds but paradoxically in many cases lack an understanding of the word "innovation", do not known what the word means exactly and what innovation can be, core of their characteristics is unknown, what and how to achieve through innovation what the results will be. In scientific literature the words "inventions" and "innovation" are mixed, sometimes even used as synonyms. The invention is only the beginning of the transformation process (Gyurácz-Németh et al 2013), and innovation is a more complex concept.

Problem. Even among scientists there is no consensus on how innovation is defined, what it is and what the economic effect is generated by innovations, the definition is constantly changing. Defining innovation concept remains a serious subject of debate and continuous analysis (Mei et al, 2010). Different authors present different attitudes, emphasize different criteria or aspects of the innovation's content (Carvalho \& Sarkar, 2014).

Purpose. The aim of this paper is to define the concept of innovations and identify the changes in the concept by reviewing the scientific literature.

Object. The concept of innovations and its changes.

1 Edita Baranskaitė

Klaipèda University, PhD student. Scientific interests: tourism innovations economic impact

E-mail: edita.baranskaite@ku.lt

2 Daiva Labanauskaite

Klaipeda University, associate professor, $\mathrm{PhD}$. Scientific interests: tourism, the economics of services

E-mail: labanauskaite.daiva@gmail.com 
Tasks: To analyze research literature on novelty approach in the concept of innovations; to systemize scientific literature on innovations concept based on process of interaction; to analyze the innovations term from the perspective of value creation; to analyze the concept of innovations as a factor of social progress.

Methods. Scientific literature analysis method was used to achieve the aim.

\section{Novelty approach in the concept of innovation}

Analysis of the scientific literature on the concept of innovation reveals that despite a lot of differences between different theories of authors, there are also some connecting points. In defining the concept of innovation, several different groups of scientific approaches can be systematized by different criteria.

The oldest approach group identifies innovation as novelty. This is the earliest trend in innovation research. The word "innovation" comes from "innovare" and the Latin noun "innovatus". The meaning on the word is to create or make something new by transforming an idea or process into a demanded product or added value service (Johannessen et al., 2001). Scientists started to investigate innovations topic in 20th century. J. Schumpeter (1934) was in a forefront of innovations theory, he was one of the first scientists who created innovations theory. The scientist had already a quite broad approach of the innovations concept, encompassing new products, new production processes, new markets, new materials and new organizational forms. Schumpeter (1934) stated that the common aspect between all these „new things“ is that they are characterized by "new combinations", which is important for companies, dynamic business leaders and entrepreneurs (Otterbacher, 2008). Innovation is a new way of doing things, or it describes new or unique combinations of factors of production. Innovation was broadly defined as the development of an organization and the implementation of new products or services, new ways of doing things (Schumpeter, 1934).

J. Shumpeter's attitude that innovation is any novelty related to a product, activity or organization was a sound basis for further researches. Many later scientists (Steele, 1975; Mansfield, 1963; Rieche \& Schön, 1966 ; Damanpour, 1992 and many others) held the same idea that innovation is the assimilation of a new idea, behaviour, system, policy, program, device, process, product or service that are new to the organization. From an economic perspective innovation is a new activity that leads to economic growth. Innovation is essentially a process of creating change, and while such change can be dangerous and the concept of innovation is vague, it is simply described as "the introduction of new things or methods". Later Drucker (1985) defined innovation simply as an opportunity that results in the creation of new products or services. The link between innovation and novelty is also emphasized in official publications. OECD Oslo Manual (2005) indicates that the innovation is a new and or significantly improved goods or services, the process of implementation a new marketing method or a new organizational method in business, job organization or external relations. Nowadays the definition of innovation does not necessarily imply a major change in relation to a particular individual (Decelle, 2004). Most definitions of innovation has novelty as key elements, but the novelty is not always something new for the world, it can be new for the company (Sipe \& Testa, 2009). Whatever the context in which innovation is discussed, it is in related to something new at any level (Mei et all, 2010) - improved areas of business related to product, service, process, marketing methods or even organizational structures are identified as innovative approach (Pirnar et al., 2012). Innovation and creativity are often misinterpreted in terms of novelty, but they mean different things because creativity involves new products and new services, new ideas, new processes, brands, techniques, methods and inventions. Creativity is the ability to generate new and useful ideas (Gyurácz-Németh et al., 2013; Sipe \& Testa, 2009), it can help to discover new problem-solving and company-specific opportunities (Otterbacher, 2008), while innovation includes new creative ideas and inventions usage (Pirnar et al., 2012). It is the ability to implement new creative ideas by solving problems through opportunities (Gyurácz-Németh et al., 2013; Sipe \& Testa, 2009). Successful innovation requires a high-level professional management and creativity combinations. The general definition of innovation from the perspective of novelty can be formulated as any novelty to a business unit as a result of a creative idea that can occur in any sphere of business. Areas of activity are not differentiated in different historical periods. Analysing the genesis of the concept of innovation in terms of 
novelty, it is noticeable that the areas of expression of innovation are becoming less specific as the definition of innovation evolves (see Table 1). In 1934, J. Shumpeter provided a sufficiently specific list of novelties, known as innovations. Later (1975-1996), innovation was called as a new activity for the business unit, not the world. Even later (2005), innovations were considered necessary new but also significantly improved objects, and the latest (2004-2013) definitions refer to innovation even less specifically as the application of creative ideas and inventions.

Table 1. Innovations concept

\begin{tabular}{|l|l|l|l|}
\hline Shumpeter, 1934 & $\begin{array}{l}\text { Mansfield, 1963; } \\
\text { Steele, 1975; } \\
\text { Damanpour, 1992 } \\
\text { Danmanpour, 1996 }\end{array}$ & OECD, 2005 & $\begin{array}{l}\text { Decelle, 2004; } \\
\text { Sipe \& Testa, 2009; } \\
\text { Pirnar, 2012; } \\
\text { Gyurácz-Németh et al, 2013 }\end{array}$ \\
\hline $\begin{array}{l}\text { New: } \\
\text { - products, } \\
\text { production processes, } \\
\text { markets, } \\
\text { raw material, } \\
\text { forms of organization } \\
\text { of activities }\end{array}$ & $\begin{array}{l}\text { New activity for the busi- } \\
\text { ness unit, not the world, } \\
\text { the process of creating } \\
\text { change. }\end{array}$ & $\begin{array}{l}\text { New or significantly im- } \\
\text { proved: } \\
\text { goods, } \\
\text { - services, } \\
\text { process, } \\
\text { marketing or business } \\
\text { organization method, } \\
\text { workplace organization } \\
\text { or external relations }\end{array}$ & $\begin{array}{l}\text { New creative ideas and inven- } \\
\text { tions of application as at any } \\
\text { level }\end{array}$ \\
\hline
\end{tabular}

Source: Created by author

However, all innovation theories are created based on doubting existing assumptions and ways of thinking. A lot of authors ignore creativity aspect in defining the concept of innovation. Creativity driven novelty in the interpretation of the concept of innovation, despite it is the oldest and one of the largest approaches, is not the only approach. Each author questions and supplements previous theories. Different actors have different perceptions of what they consider to be innovation, suggesting that previous research has not been able to provide a useful definition of innovation (Johannessen et al., 2001; Hjalager, 2010). Other viewpoints emerge from this. Much later, as research into the concept of innovation in terms of novelty has developed, other groups of approaches have emerged, emphasizing less specific and more abstract factors in defining innovation

\section{Innovation as a process of interaction}

Other researchers argue in one or another way that innovation is a process of interaction within a company. Sources of innovation are numerous and highly dependent on the economic sector in which the company operates, but regardless of the sector in which organizations operate, innovation remains an evolutionary process based on knowledge (Johannessen et al., 1999). And while it is possible for innovation to emerge in one particular organization, innovation is often the result of the interaction of several entities. Small and medium-sized enterprises are particularly rarely equipped with the knowledge resources, are needed to innovate and collaborate with other companies and to innovate, develop synergies and share competences (Müller, 2006). According to Muller and Zenker (2001), the knowledge needed for innovation can be generated by organizations internally (for example, through $\mathrm{R} \& \mathrm{D}$ ) or acquired from organizations external environment: partners, competitors, suppliers and customers (Iorgulescu et al., 2013). Innovation refers to the interaction between the various combined work production operators, new economically useful knowledge dissemination and use (Lundvall, 1992; Iorgulescu et al., 2013). There is some kind of novelty in innovations definition by interaction aspect as sharing of knowledge resources is pointed out. Knowledge is created and transferred internally or transferred from one entity to another and it is obvious that they will be new for the receiving unit (see Fig. 1). 


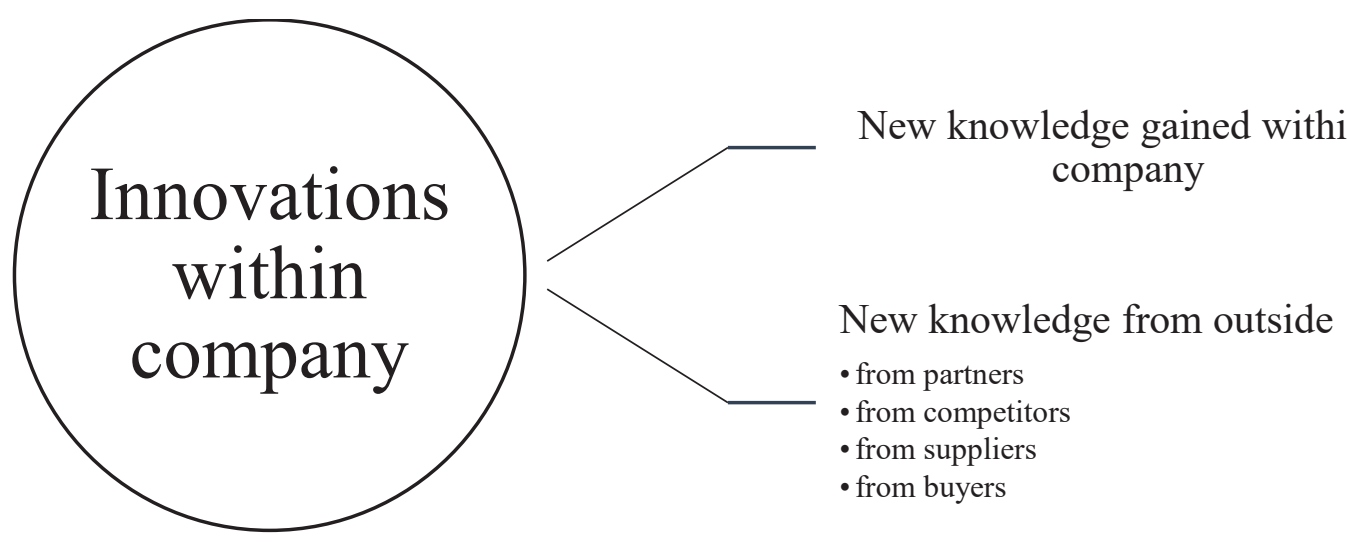

Figure 1. The concept of innovation in terms of interaction processes

Source: Created by author

The synthesis of knowledge within the company and from the outside creates the favourable conditions for innovations. This interaction results in innovations within a company.

\section{Innovation as a tool of value creation}

The third group of authors describes innovation as value creation. The explanation of innovation definition through value creation is very abstract. It limits to everything that creates value and increases competitive advantage. This trend has also emerged when the concept of innovation emphasizing novelty expanded considerably. This approach supplements but does not replace theories that interpret innovation through novelty.

In the scientific literature the link between value and innovations is described in both ways. It is explained that value creation is innovation, that increases value for customer (Maine et al., 2012). On the other hand, other authors emphasize that the product or service that has value proposition changes are already innovations (Nada, Ali, 2015). Value is identified as an important aspect of innovation (Francis, Bessant, 2005), innovation creates new opportunities to increase value added (Meneses, Teixeira, 2011). Innovations are defined as a way to create value for customers (O'Cass, Sok, 2013). Innovation concept is also defined by emphasizing a competitive advantage. Howells (2007) and Meneses, Teixeira (2011) indicate innovation as a way to maintain competitive advantage and rejuvenate mature business. Value in innovations can be created in the cooperation between innovation holder and stakeholders. It is very visible in digital innovations when value is created through social media interactions (Suseno et al., 2018).

\section{Innovations as a factor of social progress}

Other authors describe innovation through a social progress aspect. This approach group does not deny the other group of theoretical statements but emphasize different aspects. Innovations definition using social progress perspective is separated from novelty, process interaction and value creation approaches (see Fig. 2).

Innovations as a factor of social progress approach group describes innovation in the least tangible way. From a sociological point of view, innovation is the renewal of social behaviour (McCleeland, 1961; LaPiere, 1965). According to Kline and Rosenberg (1986), innovation is a complex social phenomenon. Innovation represents a joint social process (not the result), when in the end it is possible to see the usefulness of innovation (Decelle, 2004). It is defined as a process where innovation does not occur in a linear way but is characterized by complex feedback communication mechanisms and interactive communications. Innovation as an expression of human creativity and unconventional thinking is not the result of economic development, but rather a source of sustainable economic and social progress (Collins \& Fahy, 2011; Iorgulescu et al., 2013). 


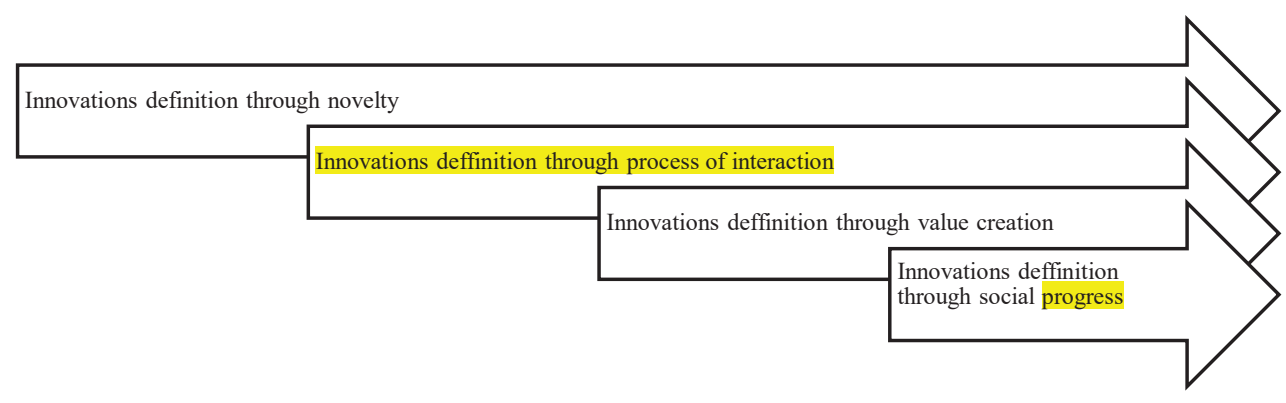

Figure 2. The concept of innovation in terms of social processes

Source: Created by author

Although the scientific literature since 1936 to 2018 revealed 4 innovation analysis trends, which can be divided into smaller parts: novelty, the interaction processes, change, value creation and social progress, J. Jemeljanovič and G. Mikaliūnienė (2016) distinguishes different four innovation areas: economic, managerial, psychologic and technologic, which can classify innovation concept definition directions. All approaches, discussed in this paper, can be classified by these main groups. In addition to economic and management approaches, psychological approach emphasizes employee's knowledge, skills and creativity as innovation knowledge is linked to people and their abilities. While technological approach focuses on new technologies, stating that innovations are everything that is created using new technologies (see Table 2).

Table 2. Classification of the concept of innovation

\begin{tabular}{|c|c|c|}
\hline \multicolumn{3}{|c|}{ ECONOMIC APPROACH } \\
\hline NEW & VALUE CREATION & COMPETITIVE ADVANTAGE \\
\hline $\begin{array}{l}\text { - Schumpeter (1934) - a new activity that leads to } \\
\text { economic growth. } \\
\text { - Steele (1975) - Introduction of new subjects or } \\
\text { methods. } \\
\text { - Drucker (1985) - Organizing and implementing new } \\
\text { products or services, new ways of doing things. } \\
\text { - Tidd (1997) Innovare - to create or make some- } \\
\text { thing new. } \\
\text { - Danmanpour (1996) - does not always mean news in } \\
\text { the world, it may be new to a business unit. } \\
\text { t Johannessen et al. (2001) - Almost every defini- } \\
\text { tion of innovation focuses on renewal. } \\
\text { improved goods or services, process implementation, } \\
\text { new marketing method or new business organization } \\
\text { method, workplace organization or external relations. } \\
\text { - Otterbacher (2008) - a combination of profes- } \\
\text { sional management and creativity. } \\
\text { - Gyurácz-Németh et al. (2013) - that innovation } \\
\text { management is the ability to implement creative ideas } \\
\text { in problem solving. } \\
\text { - Pirnar, 2012 - Application of new creative ideas } \\
\text { and inventions. } \\
\text { - Mei et al. (2010) - related to something new. } \\
\text { lated to product, service, process, marketing methods } \\
\text { or organizational structures are identified as innovative } \\
\text { approaches }\end{array}$ & $\begin{array}{l}\text { - Peters \& Pikkemaat, } 2006 \text { - } \\
\text { Transforming an Idea or Process } \\
\text { into a Demanding Product or } \\
\text { Service with Value Added } \\
\text { - Martínez- Ros and Orfila - } \\
\text { Sintes (2009) - create new oppor- } \\
\text { tunities for added value. } \\
\text { - Teixeira (2011) - Innova- } \\
\text { tion must create value for the } \\
\text { company. }\end{array}$ & $\begin{array}{l}\text { Howells (2007), and Meneses } \\
\text { \& Teixeira (2011) - A way to main- } \\
\text { tain a competitive edge and rejuve- } \\
\text { nate mature business. }\end{array}$ \\
\hline
\end{tabular}




\begin{tabular}{|c|c|c|}
\hline \multicolumn{3}{|c|}{ MANAGEMENT APPROACH } \\
\hline $\begin{array}{l}\text { INTEROPERABILITY PROCESSES WITHIN THE } \\
\text { COMPANY }\end{array}$ & CHANGES & SOCIAL PROGRESS \\
\hline $\begin{array}{l}\text { - } \quad \text { Lundvall (1992), Iorgulescu et al. (2013) - In- } \\
\text { teraction between various collaborating production } \\
\text { entities, dissemination and use of new economically } \\
\text { useful knowledge. } \\
\text { - Johannessen et al. (1999) - An evolutionary pro- } \\
\text { cess based on knowledge. } \\
\text { - MÜLLER \& pharingoesophageal, } 2001 \\
\text { - Gyurácz-Németh et al (2013) - Includes not only } \\
\text { typical product / process manufacturing innovation but } \\
\text { also market, organizational and resource innovation. } \\
\text { - Hollenstein (2000) and Carvalho \& Sarkar (2014) } \\
\text { - cover several stages, starting with the fundamental } \\
\text { introduction of new products and the introduction of } \\
\text { new manufacturing technologies in-house. }\end{array}$ & $\begin{array}{l}\text { - Steele (1975) - The process } \\
\text { of creating change. } \\
\text { - Decelle (2004) - Not neces- } \\
\text { sarily a big change for a particular } \\
\text { person. }\end{array}$ & $\begin{array}{l}\text { - McCleeland (1961), LaPiere } \\
\text { (1965) - A Renewal of Social Be- } \\
\text { havior. } \\
\text { - Kline and Rosenberg (1986) - A } \\
\text { complex social phenomenon. Rep- } \\
\text { resents the totality of the combined } \\
\text { social process (not the result). } \\
\text { - Collins \& Fahy (2011) is not the } \\
\text { result of economic development but } \\
\text { rather a source of sustainable eco- } \\
\text { nomic and social progress }\end{array}$ \\
\hline \multicolumn{3}{|c|}{ PSYCHOLOGICAL APPROACH (WORKERS ,KNOWLEDGE, SKILLS AND CREATIVITY) } \\
\hline \multicolumn{3}{|c|}{$\begin{array}{ll}\text { - } & \text { Anderson et al. (2004) } \\
\text { - } & \text { Orfila-Sintesa et al. (2005) } \\
\text { - } & \text { Tseng \& Kuo \& Chou (2008) } \\
\text { - } & \text { Gyurácz-Németh et al. (2013) - Innovation knowledge is linked to people and their abilities }\end{array}$} \\
\hline \multicolumn{3}{|c|}{ TECHNOLOGICAL APPROACH (NEW TECHNOLOGY) } \\
\hline \multicolumn{3}{|c|}{$\begin{array}{ll}\text { - } & \text { Oslo Manual (2005) } \\
\text { - } & \text { Van de Vrande et al. (2009) } \\
\text { - } & \text { Gassmann (2006) } \\
\text { - } & \text { Don Hippel (2009) } \\
\text { - } & \text { Chesbrough (2006) } \\
\text { - } & \text { Van Dijk, Van Den Ende (2002) } \\
\text { Lichtenthaler (2007) - Innovations are based on new technologies. }\end{array}$} \\
\hline
\end{tabular}

Source: Created by author

Based on the innovation concept analysis directions, listed above, the innovation concept can be defined as an enterprise or consumer initiated economic, managerial, psychological or technological process of renewal within a company, which brings greater added value and a competitive advantage. The definition of innovation concept does not reveal innovations classification aspects.

\section{Conclusions}

In summary, the development of innovations concept started in 1934, approaching the concept from the novelty perspective. This research group identified new products, services as innovations. It can be something new for the consumer, company or world. The research on innovation concept evolved and new perspectives were introduced. Innovations concept was explained as interaction processes inside and outside the company. The definition was based on the synergy between units as it enables the sharing of knowledge, transmitted knowledge helps to create new things - innovations. Later value creation approach was introduced in defining innovations concept. Scientists emphasized value aspect. Innovations were understood as new products or services, delivering higher value for consumers. The latest emerged approach group is explaining innovation through the social progress. Innovation as an expression of human creativity and unconventional thinking is not the result of economic development, but rather a source of sustainable economic and social progress. Today the innovations concept definition is wider and can be defined as following: innovation is a company or consumer-initiated economic, managerial, psychological or technological process of renewal within a company, which results in greater added value and a competitive advantage. Innovation from an economic perspective are treated as a source for competitiveness and economic growth, it is approached also as a tool for economic growth and prosperity in different countries. Innovation has become one of the top priorities in many countries for driving economy. 


\section{References}

Anderson, P., Tushman, M. L. (2004). Managing strategic innovation and change: A collection of readings. Oxford University Press.

Carvalho, L. M. C., Sarkar, S. (2014). Market structures, strategy and innovation in tourism sector. International Journal of Culture, Tourism and Hospitality Research, Vol. 8(2), p. 153-172.

Chesbrough, H. (2006). Open business models: How to thrive in the new innovation landscape. Harvard Business Press.

Collins, P., Fahy, F. (2011). Culture and creativity: A case study from the West of Ireland. Cities, Vol. 28(1), p. 28-35.

Damanpour, F. (1992). Organizational size and innovation. Organization studies, Vol. 13(3), p. 375-402.

Damanpour, F. (1996). Organizational complexity and innovation: developing and testing multiple contingency models. Management science, Vol. 42(5), p. 693-716.

De Paulo, A., De Oliveira, S., Silveira Porto, G. (2017). Mapping impacts of open innovation practices in a firm competitiveness. Journal of Technology Management \& Innovation, Vol. 12 (3), p. 108-117. Business Source Complete, EBSCOhost, viewed 2 January 2018.

Decelle, X. (2004). A conceptual and dynamic approach to innovation in tourism. OECD.

Drucker, P. F. (1985). The changed world economy. Foreign Affairs, Vol. 64, p. 768-791.

Francis, D., Bessant, J. (2005). Targeting innovation and implications for capability development. Technovation, Vol. 25(3), p. 171-183.

Gassmann, O. (2006). Opening up the innovation process: towards an agenda. R\&d Management, Vol. 36(3), p. $223-228$.

Gyurácz-Németh, P., Friedrich, N., Clarke, A. (2013). Innovation in special hotels - as a key to success. Management knowledge and learning international Conference, p. 19-21.

Gyurácz-Németh, P., Friedrich, N., Clarke, A. (2013). Innovation in special hotels-as a key to success. Management knowledge and learning international Conference, p. 19-21.

Hjalager, A. M. (2010). A review of innovation research in tourism. Tourism management, Vol. 31(1), p. 1-12.

Hollenstein, H. (2000). The determinants of foreign activities of Swiss firms: an empirical analysis based on firm-level data. 27th Annual Conference of the European Association for Research in Industrial Economics (EARIE). Swiss Institute for Business Cycle Research, Industrial Economics Research Group.

Howells, J. (2007). Services and innovation: conceptual and theoretical perspectives. The Handbook of Service Industries, chapter 3. Edward Elgar Publishing.

Iorgulescu, M. C., Răvar, A. S. (2013). Measuring managers' perception of innovation in the Romanian hospitality industry. Procedia Economics and Finance, Vol. 6, p. 512-522.

Jemeljanovič, J., Mikaliūnienė, G. (2016). Paslaugų įmonių inovatyvumo vertinimas. VU EF studentu mokslinės draugijos konferencija: straipsniu rinkinys, 2015, p. 92-101.

Johannessen, J. A., Olsen, B., Lumpkin, G. T. (2001). Innovation as newness: what is new, how new, and new to whom? European Journal of innovation management, Vol. 4(1), p. 20-31.

Johannessen, J. A., Olsen, B., Olaisen, J. (1999). Aspects of innovation theory based on knowledge-management. International journal of information management, Vol. 19(2), p. 121-139.

Kline, S. J., Rosenberg, N. (1986). An overview of innovation. The positive sum strategy: Harnessing technology for economic growth. The National Academy of Science, USA.

LaPiere, R. T. (1965). Social change. McGraw-Hill Book Company.

Lichtenthaler, U. (2007). The drivers of technology licensing: An industry comparison. California management review, Vol. 49(4), p. 67-89.

Lundvall, B. (1992). National systems of innovation: towards a theory of innovation and interactive learning. London: Pinter.

Maine, E., Lubik, S., Garnsey, E. (2012). Process-based vs. product-based innovation: Value creation by nanotech ventures. Technovation, Vol. 32(3-4), p. 179-192.

Mansfield, E. (1963). Size of firm, market structure, and innovation. Journal of Political Economy, Vol. 71(6), p. 556-576.

McClelland, D. C. (1961). Achieving society. Princeton, N. J., Van Nostrand, 512 p.

Mei, X. Y., Arcodia, C., Ruhanen, L. (2010). A National Government's Tourism Innovation Initiatives: A Review of Tourism Development Policies in Norway. In the 21st Council for Australian University Tourism and Hospitality Education annual conference (CAUTHE 2011). Sydney.

Meneses, O. A., Teixeira, A. A. (2011). The innovative behaviour of tourism firms. Economics and Management Research Projects: An International Journal, Vol. 1(1), p. 25-35.

Müller, D. (2006). Unplanned development of literary tourism in two municipalities in rural Sweden. Scandinavian Journal of Hospitality and Tourism, Vol. 6(3), p. 214-228.

Muller, E., Zenker, A. (2001). Business services as actors of knowledge transformation: the role of KIBS in regional and national innovation systems. Research policy, Vol. 30(9), p. 1501-1516. 
Nada, N., Ali, Z. (2015). Service value creation capability model to assess the service innovation capability in SMEs. Procedia CIRP, Vol. 30, p. 390-395.

O'Cass, A., Sok, P. (2013). Exploring innovation driven value creation in B2B service firms: The roles of the manager, employees, and customers in value creation. Journal of Business Research, Vol. 66(8), p. 1074-1084.

Orfila-Sintes, F., Crespi-Cladera, R., Martínez-Ros, E. (2005). Innovation activity in the hotel industry: Evidence from Balearic Islands. Tourism Management, Vol. 26(6), p. 851-865.

Oslo Manual. (2005). Guiddelines for collecting and interpreting innovation data. Oslo Manual. ISBN 92-64-01308-3, p. 164.

Ottenbacher, M. (2008). Innovation management. Handbook of hospitality operations and IT. Elsevier Ltd., Oxford, p. 340-366.

Peters, M., Pikkemaat, B. (2006). Innovation in tourism. Journal of Quality Assurance in Hospitality \& Tourism, Vol. 6(3-4), p. 1-6.

Pirnar, I., Bulut, C., Eris, E. D. (2012). Improving the performance and competitiveness of tourism establishments by means of innovation: trends and applications. In Proceedings of IRAT "Enlightening Tourism” Conference. Naples, Italy, p. 211.

Schumpeter, J. A. (1934). The theory of economic development, translated by Redvers Opie. Economic Studies, p. 46. Harvard.

Sipe, L. J., Testa, M. (2009). What is Innovation in the Hospitality and Tourism Marketplace? A Suggested Research Framework and Outputs Typology, International CHRIE Conference-Refereed Track. Paper 22.

Steele, L. W. (1975). Innovation in big business. Elsevier Publishing Company.

Suseno, Y., Laurell, C., Sick, N. (2018). Assessing value creation in digital innovation ecosystems: A Social Media Analytics approach. The Journal of Strategic Information Systems, Vol. 27(4), p. 335-349.

Tidd, J. (1997). Complexity, networks \& learning: Integrative themes for research on innovation management. International Journal of Innovation Management, Vol. 1(01), p. 1-21.

Tseng, C. Y., Kuo, H. Y., Chou, S. S. (2008). Configuration of innovation and performance in the service industry: evidence from the Taiwanese hotel industry. The Service Industries Journal, Vol. 28(7), p. 1015-1028.

Van de Vrande, V., De Jong, J. P., Vanhaverbeke, W., De Rochemont, M. (2009). Open innovation in SMEs: Trends, motives and management challenges. Technovation, Vol. 29(6-7), p. 423-437.

Van Dijk, C., Van Den Ende, J. (2002). Suggestion systems: transferring employee creativity into practicable ideas. $R \& D$ Management, Vol. 32(5), p. 387-395.

Von Hippel, E. (2005). Democratizing innovation: The evolving phenomenon of user innovation. Journal für Betriebswirtschaft, Vol. 55(1), p. 63-78.

\title{
I NOVACIJU KONCEPCIJA NAUJUMO, VERTÉS KÜRIMO,SAZVIKOS PROCESO IR SOCIALINĖS PAŽANGOS POŽIŪRIAIS
}

\author{
Edita Baranskaité, Daiva Labanauskaité \\ Klaipėdos universitetas (Lietuva)
}

\section{Santrauka}

Šalys ir verslai, siekdami mažinti sąnaudas ir didinti pelną, šiuo metu siekia optimizuoti procesus. Pagrindinis žodis - inovacijos. Tai viena populiariausių tendencijų daugelyje ekonomikų ir verslo įmonių. Paradoksalu, kad trūksta sąvokos aiškumo tiek versle, tiek moksle. Inovacijų terminas mokslinėje literatūroje nenaujas. Problema ta, kad šios sąvokos apibrèžimas nuolat kinta, ji aiškiai neapibrezžta. Mokslininkai nèra sutarę dèl to, kaip apibrèžti inovacijas, kas jos yra ir kokị ekonominị poveikị teikia. Yra daug skirtingų požiūrių, pabrěžiant skirtingus inovacijos turinio kriterijus ar aspektus. Inovacijų sampratos apibrèžimas tebèra rimtas diskusijų ir nuolatinès analizès objektas. 
Šio straipsnio tikslas - apibrèžti inovacijų sąvoką ir nustatyti, kaip apibrěžimas kito, apžvelgiant mokslinę literatūrą. Siekiant iškelto tikslo, taikytas mokslinès literatūros analizès metodas.

Literatūros analizè atskleidè, kad inovacijų koncepcija pradèta analizuoti $1934 \mathrm{~m}$. Pirmieji inovacijas analizavę mokslininkai jas apibrèžè kaip naujovę. J. Shumpeterio požiūris, kad inovacijos - tai kiekviena naujovè, susijusi su produktu, veikla ar organizacija, buvo tvirtas pagrindimas tolesniems tyrimams. Analizuojant inovacijas naujumo aspektu teigiama, kad žvelgiant iš ekonominès perspektyvos, inovacijos yra nauja veikla, lemianti ekonomikos augimą. Daugelyje inovaciju apibrèžimų naujumas yra pagrindinis elementas, bet jos ne visada yra kažkas naujo pasauliui, gali būti nauja tik įmonei. Nagrinejjant inovacijų sąvokos vartojimą išryškèjo kitos požiūrių grupès, pabrèžiančios mažiau specifinius, abstraktesnius veiksnius apibrèžiant inovacijas.

Kiti tyrẻjai vienaip ar kitaip tvirtina, kad inovacijos yra skirtingų subjektų sąveikos procesas įmonès viduje. Jos gali atsirasti vienoje konkrečioje organizacijoje, bet dažnai būna kelių subjektų sąveikos rezultatas. Ypač retai mažos ir vidutinès įmonès turi žinių išteklių, joms būtina bendradarbiauti su kitomis įmonèmis, kad pasidalintų kompetencijomis, ịvyktų sinergija ir taip būtų sukurtos inovacijos. Žinios kuriamos ir perduodamos viduje arba perkeliamos iš vieno subjekto kitam, akivaizdu, kad priimančiam subjektui jos bus naujos, inovatyvios. Žinių sinteze įmonejje ir iš išorès sudaro palankias sąlygas inovacijoms. Ši sąveika lemia jų atsiradimą ịmoneje.

Trečia autorių grupe inovacijas apibūdina kaip vertès - konkurencinio pranašumo - kūrimą. Inovacijų, kaip vertès kūrimo, apibrèžimas yra labai abstraktus: apima viską, kas kuria vertę ir didina konkurencinị pranašumą.

Vèliau inovacijų sąvoka aiškinta dar abstrakčiau, apibūdinta pasitelkus socialinès pažangos aspektą. Ši požiūrio grupè inovacijas ịvardija mažiausiai specifiškai. Inovacijos apibrèžiamos kaip procesas, vykstantis nelinijiniu būdu, bet apibūdinamos sudètingais grịžtamojo ryšio perdavimo mechanizmais ir interaktyvia komunikacija. Jos traktuojamos kaip žmogaus kūrybiškumo ir netradicinio mąstymo išraiška, yra ne ekonominio vystymosi rezultatas, o darnios ekonominès ir socialinès pažangos šaltinis.

Visos inovacijų koncepcijos apibrezžimo kryptys yra skirtingos. Nė viena iš analizuotų krypčių grupių neneigia kitos teorinių teiginių grupès, tik pabrēžia skirtingus aspektus. Šiandien inovacijų sąvoka gali būti apibrezżiama kaip įmonès ar vartotojo inicijuotas ekonominis, vadybinis, psichologinis ar technologinis atnaujinimo procesas, kuris sukuria didesnę pridètinę vertę ir konkurencinị pranašumą.

PAGRINDINIAI ŽODŽIAI: inovaciju koncepcija, inovacijos ekonomikoje.

JEL KLASIFIKACIJA: O31, O39.

Received: 2020-

Revised: 2020-

Accepted: 2020- 